\title{
Correction to: Genome-wide association study to identify chromosomal regions related to panicle architecture in rice (Oryza spp.)
}

\author{
Ranjita Thapa $\cdot$ Rodante E. Tabien $\cdot$ Endang M. Septiningsih $(\mathbb{D}$
}

Published online: 22 April 2021

(C) Springer Nature B.V. 2021

\section{Correction to:}

Genet Resour Crop Evol

https://doi.org/10.1007/s10722-021-01159-8

"The original version of this article contained several typos and minor mistakes, because the proof corrections were not carried out by the publisher. The original article has been corrected."

Publisher's Note Springer Nature remains neutral with regard to jurisdictional claims in published maps and institutional affiliations.

The original article can be found online at https:// doi.org/10.1007/s10722-021-01159-8.

R. Thapa · E. M. Septiningsih $(\bowtie)$

Department of Soil and Crop Sciences, Texas A\&M

University, College Station, TX 77843, USA

e-mail: eseptiningsih@tamu.edu

Present Address:

R. Thapa

Department of Agronomy and Horticulture, University of

Nebraska-Lincoln, Lincoln, NE 68583, USA

R. E. Tabien

Texas A\&M AgriLife Research Center, Beaumont,

TX 77713, USA 